\title{
Bilateral Pseudoarthrosis of the Clavicles without Cbfa1/ Runx2 Gene Mutation: A Case Report
}

\author{
Thomas D ${ }^{1}$, Sandow MJ $^{2}$, Evdokiou $\mathrm{A}^{3}$ and Findlay \\ DM ${ }^{3 *}$ \\ ${ }^{1}$ Department of Medicine, University of Melbourne at St \\ Vincent's Hospital, Fitzroy, Australia \\ ${ }^{2}$ Department of Orthopaedics and Trauma, Royal \\ Adelaide Hospital, Adelaide, Australia \\ ${ }^{3}$ Discipline of Orthopaedics and Trauma, University of \\ Adelaide, Adelaide, Australia \\ *Correspondling author: David M Findlay, Discipline \\ of Orthopaedics and Trauma, Adelaide Health and \\ Medical Sciences Building, University of Adelaide, North \\ Terrace, Adelaide, South Australia 5000, Australia
}

Received: August 18, 2017; Accepted: September 18, 2017; Published: September 25, 2017

\begin{abstract}
We have identified an individual with bilateral pseudoarthrosis of the clavicle, presumed to be congenital, with no family history of the condition, no evidence of postnatal trauma to the clavicles and no other overt skeletal abnormalities. The genetic basis of pseudoarthrosis of the clavicle has not been identified, although Cleidocranial Dysplasia (CCD), a congenital condition characterized by skeletal anomalies that include hypoplastic and/or aplastic clavicles, has been mapped to chromosome $6 \mathrm{p} 21$ and shown to result from mutations in the Cbfa1/ runx2 gene. We therefore investigated the possible involvement of Cbfa1/runx2 mutation by sequencing all 7 exons of the gene. No changes were found in the coding sequence of Cbfa1/runx2 in this case of pseudoarthrosis of the clavicles and the genetic basis for congenital pseudoarthrosis of the clavicles remains to be determined.
\end{abstract}

Keywords: Clavicle; Bilateral Pseudoarthrosis; Cbfa1 gene

\section{Case Presentation}

We report a case of bilateral pseudoarthrosis of the clavicles in a 21 year-old white male, who was otherwise skeletally normal and showed no adverse effects from his condition. His parents and a younger female sibling were unaffected. Since visualisation of the clavicle is suboptimal using standard radiographs, a high resolution shoulder-to-neck CT, with $0.5 \mathrm{~mm}$ slice thickness, was performed. $3 \mathrm{D}$ reconstruction of the CT was performed using True Life Anatomy software (TLA Generator, Rubamas, Adelaide; www.rubamas.com) to create a surface rendered model of the upper thorax showing skin, clavicles and lungs as separate objects. Figure 1 demonstrates clearly the complete discontinuity at the midshaft of both clavicles. The overall alignment was reasonable, although there was inferior displacement of the lateral fragment with respect to the medial shaft. The appearance was symmetrical, and the clavicles were well aligned with the thorax. There was no significant tendency for medialisation of the shoulder girdle. There was no particular overriding of the clavicles, which was explained after further manipulation of the $3 \mathrm{D}$ images, using different image thresholds, revealed a cartilage anlage joining the ends of the clavicles together (not shown). This would explain the relatively stable position of the shoulder girdle, despite the apparent discontinuity, as distinct from the normal overriding following acute clavicular fracture.

To identify mutations in coding regions of the Cbfa1/runx 2 gene, peripheral blood was taken from the subject and white blood cells were harvested to prepare chromosomal DNA, using standard procedures. The Cbfa1/runx 2 exons were amplified using intron- and exon-specific primers shown in Figure 2 [1]. No mutation in any coding region or splice-donor/acceptor sites in the Cbfa1/runx 2 gene was identified.

\section{Discussion}

Congenital pseudoarthrosis of the clavicle is a rare condition, whose aetiology and true prevalence are unknown. The condition is usually benign and rarely produces any functional impairment, although occasionally a progressive swollen deformity [2], or venous thoracic outlet syndrome [3], can occur. Surgical repair is sometimes undertaken when symptoms limit activities of daily living or engender aesthetic concerns $[4,5]$. Most commonly, there is a defect in the shaft of one clavicle and, in a large series, these were overwhelmingly on the right side [2]. Rarely, the defect occurs bilaterally [6,7]. The origins of congenital pseudoarthrosis may be in early embryogenesis, since the clavicle is the first of all bones to ossify in mammals [8]. The clavicle appears in the seventh week of gestation as two centres of ossification, which spread during the eighth week towards the sternum and towards the acromium, ossification being preceded by a formation of true cartilage [8]. Arrest or interruption of this process may prevent the union of the two ossific centres of the clavicle.

No convincing genetic pattern has been identified and no gene has been implicated in congenital pseudoarthrosis of the clavicle. There is a rare variant of bilateral congenital pseudoarthrosis reported to accompany pycnodysostosis, due to cathepsin $\mathrm{K}$ deficiency, but this syndrome has generalised skeletal features, including short stature and altered bone quality [9], which did not match the case we describe here. Our rationale for investigating $C b f a 1 /$ runx 2 as a candidate gene was that Cbfa1/runx 2 mutations, in both mice and humans, are associated with skeletal abnormalities that include hypoplastic clavicles $[10,11]$. Specifically, Cleidocranial Dysplasia (CCD) is an autosomal dominant disorder characterized by skeletal anomalies that may include some or all of, patent fontanelles, persistently open or delayed closure of cranial sutures, dental abnormalities, hypoplastic and/or aplastic clavicles, and short stature $[12,13]$. The locus for CCD has been mapped to chromosome 6p21 [14], and shown to result from mutations in the Cbfa1/runx2 gene [12]. Cbfa1/runx2 is a member of the runt family of transcription factors and its expression is restricted to bone and cartilage [15]. Mice with a homozygous mutation in Cbfa1/runx2 died just after birth due to respiratory difficulties and
Austin J Orthopade \& Rheumatol - Volume 4 Issue 3 - 2017 ISSN: 2472-369X | www.austinpublishing group.com Findlay et al. (C) All rights are reserved
Citation: Thomas D, Sandow MJ, Evdokiou A and Findlay DM. Bilateral Pseudoarthrosis of the Clavicles without Cbfa1/Runx2 Gene Mutation: A Case Report. Austin J Orthopade \& Rheumatol. 2017; 4(3): 1056. 


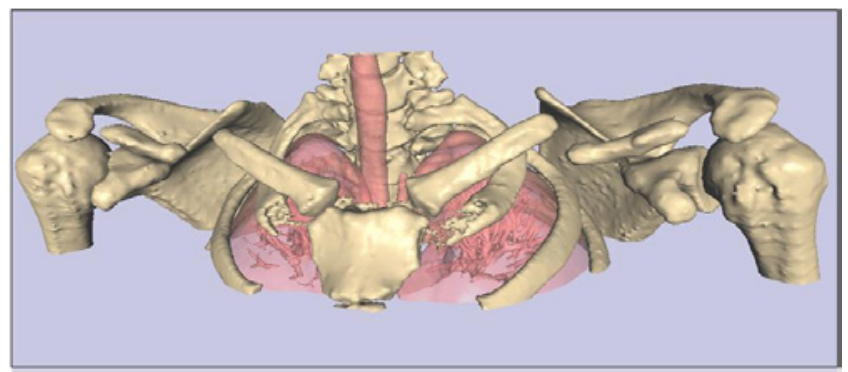

Figure 1: 3D reconstruction of a CT of the shoulders, showing bilatera disruption of the clavicles. Note that using different CT image thresholds, a cartilage anlage, not shown here, was visualised joining the midsection of the clavicles together.

\begin{tabular}{|c|c|c|}
\hline EXON & & $\begin{array}{c}\text { PRIMER SEQUENCES } \\
\text { SENSE (S), ANTISENSE (AS) }\end{array}$ \\
\hline A & & $\begin{array}{l}\text { GCT ATT TGG AAA AGC TAG CAG } \\
\text { ATG GTT AAT CTC CGC AGG TCA }\end{array}$ \\
\hline B & & $\begin{array}{l}\text { CCC GGC CAC TTC GCT AAC TTG } \\
\text { TCC GCC GCT CCC GGC CGG }\end{array}$ \\
\hline 1 & & $\begin{array}{l}\text { AAC ACT AAG TCC TGA TAA GAC } \\
\text { GAAGGT GCT GAT TTG TAT ACA }\end{array}$ \\
\hline 2 & & $\begin{array}{l}\text { AAT TTA GAA GAA GGA GTC CTG } \\
\text { AAA TAT ATG CAG ATA GCA AAG }\end{array}$ \\
\hline 3 & & $\begin{array}{l}\text { ATT CCT TGG CTT AAA CTC CCA G } \\
\text { GCC GCT TCA CAG CTC CAG G }\end{array}$ \\
\hline 4 & & $\begin{array}{l}\text { TAAGGCTGCAATGGTTGCTAT } \\
\text { GTCACTGTGAGCATGGATGAG }\end{array}$ \\
\hline 5 & & $\begin{array}{l}\text { CTC TGG GAA ATA CTA ATG AGG GA } \\
\text { AGT GCC ATG ATG TGC ATT TGT AAT }\end{array}$ \\
\hline 6 & $\begin{array}{l}\mathbf{S} \\
\mathbf{A S}\end{array}$ & $\begin{array}{l}\text { TGT GGC TTG CTG TTC CTT TAT G } \\
\text { GAT ACC ACT GGG CCA CTG CT }\end{array}$ \\
\hline
\end{tabular}

Figure 2: Primers for the PCR amplification of Cbfa1/runx2.

examination of their skeletons showed a complete lack of ossification [16]. Both intramembranous and endochondral ossification were completely blocked, owing to the maturational arrest of osteoblasts in the mutant mice, demonstrating that Cbfa1/runx2 plays an essential role in osteogenesis. Interestingly, heterozygous Cbfa1/runx2 mutant mice display symptoms very similar to human CCD, including hypoplastic clavicles $[10,11]$. Subsequently, it was found that another transcription factor, osterix (Osx), acts downstream of Cbfa1/runx 2 and is required for osteoblast differentiation and bone formation [17]. Cbfa1/runx2 null mice do not express Osx. A third transcription factor, $\mathrm{CbfB}$ is expressed in developing bone and interacts functionally with Cbfa1/runx2. Disruption of the CbfB gene resulted in a delay in endochondral and intramembranous ossification as well as in chondrocyte differentiation, similar to but less severe than delays observed in Runx2(-/-) mice [18].

Sequencing of the coding sequence of the Cbfa1/runx2 gene in the proband did not reveal any mutations. It remains possible that causative mutations exist in non-coding regions of the gene, including introns or regulatory domains. It is also possible that mutations in proteins that regulate the levels of Cbfa1/runx2, or participate in transcription complexes with it, or lie downstream from it, could lead to abnormal bone development. Cbfa1/runx 2 activity is modulated by a large number of proteins, including Cbfb, TAZ, MOZ/MORF, STAT1, MSX2, DLX5 and HES1 [23,24]. Indeed, tetranucleotide duplication in the MSX2 homeobox gene (505-508dupATTG) has been reported to segregate with a condition known as Parietal Foramina with Cleidocranial Dysplasia (PFMCCD), which also displays deficient ossification of the clavicles [25]. It is not known how mutations in $C b f a 1 /$ runx2 and other interacting molecules can lead to differential effects across the skeleton or to different penetrance in different individuals. However, the early and distinct development of the clavicles [8] could render these bones particularly sensitive to mutations in certain genetic backgrounds or to environmental influences in early foetal life. An additional possibility is that the current case was caused by epigenetic and/or environmental factors.

\section{Conclusion}

An otherwise healthy young man was identified with bilateral pseudoarthrosis of the clavicles, and no other skeletal abnormalities. Because of its involvement in Cleidocranial Dysplasia (CCD), manifestations of which can include hypoplastic and/or aplastic clavicles, we investigated the possible involvement of Cbfa1/runx2. However, no mutations were found in the coding regions of the Cbfa1/runx2 gene and the genetic basis for this condition remains to be determined. It is likely that identification of the gene or genes associated with pseudoarthrosis of the clavicles will provide fresh insights into skeletal development in general, and into that of the unique and interesting clavicular bone in particular.

\section{Acknowledgement}

This work was supported by grants from the National Health and Medical Research Council of Australia, the Adelaide Bone and Joint Research Foundation, the University of Adelaide, and the Royal Adelaide Hospital. A Evdokiou was a recipient of an SA Cancer Foundation Associateship and D Thomas was a recipient of a National Health and Medical Research Council of Australia RD Wright Research Fellowship.

\section{References}

1. Lee B, Thirunavukkarasu K, Zhou L, Pastore L, Baldini A, Hecht J, Geoffroy $V$ et al. Missense mutations abolishing DNA binding of the osteoblast-specific transcription factor OSF2/CBFA1 in cleidocranial dysplasia. Nat Genet. 1997; 16: 307-310.

2. Owen R. Congenital pseudarthrosis of the clavicle. J Bone Joint Surg Br. 1970; 52: 644-652.

3. Lozano P, Doaz M, Riera R, Gomez FT. Venous thoracic outlet syndrome secondary to congenital pseudoarthrosis of the clavicle. Presentation in the fourth decade of life. Eur J Vasc Endovasc Surg. 2003; 25: 592-593.

4. Galvin JW, Dannenbaum JH $4^{\text {th }}$, Grassbaugh JA, Eichinger JK. Pseudarthrosis of the clavicle. Orthopedics 2014; 37: 349-50.

5. Di Gennaro GL, Cravino M, Martinelli A, Berardi E, Rao A, Stilli S, et al. Congenital pseudarthrosis of the clavicle: a report on 27 cases. J Shoulder Elbow Surg. 2017; 26: e65-e70.

6. Padua R, Romanini E, Conti C, Padua L, Serra F. Bilateral congenital pseudarthrosis of the clavicle report of a case with clinical, radiological and neurophysiological evaluation. Acta Orthop Belg 1999; 65: 372-375. 
7. Russo MT, Maffulli N. Bilateral congenital pseudarthrosis of the clavicle. Arch Orthop Trauma Surg. 1990; 109: 177-178.

8. Ogata S, Uhthoff HK. The early development and ossification of the human clavicle--an embryologic study. Acta Orthop Scand. 1990; 61: 330-334.

9. Karakurt L, Yilmaz E, Belhan O, Serin E. Pycnodysostosis associated with bilateral congenital seudarthrosis of the clavicle. Arch Orthop Trauma Surg 2003; 123: 125-127.

10. Otto F, Thornell AP, Crompton T, Denzel A, Gilmour KC, Rosewell IR, et al. Cbfa1, a candidate gene for cleidocranial dysplasia syndrome, is essentia for osteoblast differentiation and bone development. Cell. 1997; 89: 765-771.

11. Huang LF, Fukai N, Selby PB, Olsen BR, Mundlos S. Mouse clavicular development: analysis of wild-type and cleidocranial dysplasia mutant mice. Dev Dyn. 1997; 210: 33-40.

12. Quack I, Vonderstrass B, Stock M, Aylsworth AS, Becker A, Brueton L, et al. Mutation analysis of core binding factor $A 1$ in patients with cleidocranial dysplasia. Am J Hum Genet. 1999; 65: 1268-1278.

13. Otto $\mathrm{F}$, Kanegane $\mathrm{H}$, Mundlos $\mathrm{S}$. Mutations in the RUNX2 gene in patients with cleidocranial dysplasia. Hum Mutat. 2002; 19: 209-216.

14. Mundlos S, Mulliken JB, Abramson DL, Warman ML, Knoll JH, Olsen BR. Genetic mapping of cleidocranial dysplasia and evidence of a microdeletion in one family. Hum Mol Genet. 1995; 4: 71-75.

15. Ducy P, Zhang R, Geoffroy V, Ridall AL, Karsenty G. Osf2/Cbfa1: a transcriptional activator of osteoblast differentiation. Cell. 1997; 89: 747-754.

16. Komori T, Yagi H, Nomura S, Yamaguchi A, Sasaki K, Deguchi K, et al. Targeted disruption of $\mathrm{Cbfa} 1$ results in a complete lack of bone formation owing to maturational arrest of osteoblasts. Cell. 1997; 89: 755-764.
17. Nakashima K, Zhou X, Kunkel G, Zhang Z, Deng JM, Behringer RR, et al. The novel zinc finger-containing transcription factor osterix is required for osteoblast differentiation and bone formation. Cell. 2002; 108: 17-29.

18. Kundu M, Javed A, Jeon JP, Horner A, Shum L, Eckhaus M, et al. Cbfbeta interacts with Runx2 and has a critical role in bone development. Nat Genet. 2002; 32: 639-644.

19. Zhou G, Chen Y, Zhou L, Thirunavukkarasu K, Hecht J, Chitayat D, et al. CBFA1 mutation analysis and functional correlation with phenotypic variability in cleidocranial dysplasia. Hum Mol Genet. 1999; 8: 2311-2316.

20. Golan I, Preising M, Wagener $\mathrm{H}$, Baumert U, Niederdellmann $\mathrm{H}$, Lorenz $B$, et al. A novel missense mutation of the CBFA1 gene in a family with cleidocranial dysplasia (CCD) and variable expressivity. J Craniofac Genet Dev Biol. 2000; 20: 113-120.

21. Goseki-Sone M, Orimo H, Watanabe A, Hamatani R, Yokozeki M, Ohyama $\mathrm{K}$, et al. Identification of a novel frameshift mutation (383inst) in the RUNX2 (PEBP2 alpha/CBFA1/AML3) gene in a Japanese patient with cleidocranial dysplasia. J Bone Miner Metab. 2001; 19: 263-266.

22. Sakai N, Hasegawa H, Yamazaki Y, Ui K, Tokunaga K, Hirose R, et al. A case of a Japanese patient with cleidocranial dysplasia possessing a mutation of CBFA1 gene. J Craniofac Surg. 2002; 13: 31-34.

23. Hermanns $P$, Lee $B$. Transcriptional dysregulation in skeletal malformation syndromes. Am J Med Genet. 2001; 106: 258-271.

24. Otto F, Lubbert M, Stock, M. Upstream and downstream targets of RUNX proteins. J Cell Biochem. 2003; 89: 9-18.

25. Garcia-Minaur S, Mavrogiannis LA, Rannan-Eliya SV, Hendry MA, Liston WA, Porteous ME, et al. Parietal foramina with cleidocranial dysplasia is caused by mutation in MSX2. Eur J Hum Genet. 2003; 11: 892-895
Austin J Orthopade \& Rheumatol - Volume 4 Issue $3-2017$ ISSN: 2472-369X | www.austinpublishinggroup.com

Findlay et al. () All rights are reserved
Citation: Thomas D, Sandow MJ, Evdokiou A and Findlay DM. Bilateral Pseudoarthrosis of the Clavicles without Cbfa1/Runx2 Gene Mutation: A Case Report. Austin J Orthopade \& Rheumatol. 2017; 4(3): 1056. 